\title{
THE RELIGIOUS LIVES OF EUROPEAN TURKS; THE ROLE OF RELIGIOUS GROUPS*
}

Yakup ÇOŞTU**

Citation/(): Çoştu, Yakup (2017). The Religious Lives of European Turks; The Role of Religious Groups, Hitit University Journal of Social Sciences Institute, Year 10, Issue 2, December 2017, pp. 785-796

Abstract: Referring the Turks that migrated to European countries as 'temporary workers' in 1960, it is obvious that neither the Turkey nor the receiving countries had no policy about migration because of the thought that they would 'go back to their homeland'. Since late 1970s, the receiving countries' points of view have changed in the way that Turks were not be temporary but permanent. So they developed some strategies and policies. The purpose of these new laws/policies was to take the migration wave under the control and supporting immigrant integration in Europe. Turkey as an emigration country, during those days, started to take some serious steps about preventing its own citizens from assimilation and helping them to integrate successfully.

During the migration period, from the early 1960s to the middle of 1980s, there was no official religious services for Turkish immigrants. For about 20 years, those people had been destined to be on their own. Within that period religious services had also been carried out mostly by some Turkey based religious groups, communities and movements. In this paper, the influence of Turkey-connected religious groups and communities on the daily religious life of European Turkish will be evaluated with a macro-sociological point of view.

Keywords: European Turks, Daily Religious Life, Religious Groups and Movements

\footnotetext{
Makale Geliş Tarihi: 31.10.2017/ Makale Kabul Tarihi: 13.11.2017

* This article is the revised and amended version of my paper was presented at "The Migration Conference" (23-26 August 2017, Harokopio University, Athens/Greece).

** Associate Professor Doctor (Doç. Dr.), Hitit University, Faculty of Divinity, Sociology of Religion Department, Çorum/Turkey, e-posta: yakupcostu@hitit.edu.tr
} 


\section{Avrupalı Türklerin Dinsel Yaşamı; Dini Grupların Rolü}

Atıf/C: Çoştu, Yakup (2017). Avrupalı Türklerin Dinsel Yaşamı; Dini Grupların Rolü. Hitit Üniversitesi Sosyal Bilimler Enstitüsü Dergisi, Yıl 10, Sayı 2, Aralık 2017, ss.785-796

Özet: 1960'larda Avrupa'nın çeşitli ülkelerine "konuk işçi” olarak göç eden Türklerle ilgili olarak, hem gönderen ülke Türkiye'nin, hem de göç edilen ülkelerin "geri dönecekler" düşüncesiyle, göçün ilk yıllarında her hangi bir politika belirlemedikleri görülmektedir. 1970'li yılların sonlarından itibaren Türk işçilerin geçici olmayıp kalıcı oldukları kanaati oluşmaya başlayınca, göç alan ülkeler bu göçmen işçilere yönelik bir takım çalışmalar başlatmışlardır. Bu politikaların temel amact, göç dalgasının kontrol altına alınması ve yaşanılan ülkeye entegrasyonun sağlanması oluşturmuştur. Gönderen ülke olarak Türkiye de, yine bu tarihlerde, Avrupa'da yaşayan vatandaşlarının asimilasyondan korunması ve yaşadıkları ülkelere başarılı bir şekilde entegrasyonlarının sağlanabilmesi için bir takım adımlar atmaya başlamıştır.

1960'ların başlarından itibaren başlayan göç sürecinde, 1980'lerin ortalarına kadar Türkiye'nin çeşitli Avrupa ülkelerinde yaşayan göçmen Türklere yönelik din hizmeti alanında resmi bir politikasının olmadığı görülmektedir. Yaklaşık yirmi yılı aşkın bu zaman dilimi göçmenlerin din konusunda kendi kaderlerine birakıldığ bir döneme işaret etmektedir. Bu zaman dilimi içerisinde din hizmeti faaliyetleri, ağırlıklı olarak Türkiye bağlantılı dini grup ve cemaatler tarafindan yürütülmeye çalışılmıştır. Bu çalışmada, Avrupalı Türk göçmenlerin gündelik dinsel yaşamında önemli bir yer işgal eden Türkiye bağlantılı dini grup ve cemaatlerin rolü makrososyolojik bir perspektiften hareketle tartışılmıştır.

Anahtar Kelimeler: Avrupalı Türkler, Gündelik Dini Yaşantı, Dini Grup ve Cemaatler

\section{INTRODUCTION}

European Turks have experienced a tough adaptation period in their host countries because the possibility of returning to their homeland has considerably decreased. Although acquiring citizenship in the host countries brings several legal achievements, they came across some problems such as the crisis of religious and national identity, a lot of conflicts of generations and cultures, and alienation. Turkish immigrants have established a number of community organizations and solidarity networks within the framework of the legal rights granted by the host country, primarily to provide services in various areas. The organizations that has been founded by European Turks are mostly mosque based foundations. ${ }^{1}$ The most important part of these organizations founded especially by Turkish immigrants who are close, followers or sympathisers of religious groups and movements in Turkey or

\footnotetext{
1 See further information: for Germany see. Perşembe, 2005; Altıntaş, 2008; Yurdakul, 2009; Yükleyen \& Yurdakul, 2011; Adigüzel, 2011. For Austria see. Kroissenbrunner, 2003. For France see. Arabac1, 1997. For Belgium see. Yanaşmayan 2010. For Netherland see. Hatunoğlu 2002; Hıdır, 2012. For Denmark see. Jorgensen 2010; Özmen, 2012, For Sweden see. Korkmaz, 2011; For Norway see. Rogstad, 2009; For Britain see. Küçükcan, 1999; Çoştu, 2013; Sirkeci et all., 2016.
} 
connected with them. These organizations were very similar to religious groups and movement in Turkey and in time they have become an institution for fulfilling differentiated demands of immigrant communities. Because of their active role in the daily religious life of European Turks analysing those civil religious organizations and the religious and cultural life around it is so valuable.

In this paper, from the beginning of the migration until today, Turkeyconnected religious groups and communities' influence on immigrants' daily religious life will be discussed with a macro-sociological point of view. Besides, the influences and reflections of their religious discourse and practice in their daily religious life will also be analysed.

\section{TURKISH IMMIGRANTS IN EUROPE AND ITS RELIGIOUS STRUCTURE}

Western European countries, soon after the Second World War focused on underdeveloped countries for supplying their lack of labour force in a development process. They have tried to supply their needs signing bilateral agreements. Within this frame, those countries focused on Turkey, and in 1961 starting with Germany bilateral labour work agreement series moved on to Austria, Belgium, Holland in 1964, France in 1965, Sweden in 1967, Switzerland in 1969 and Denmark in 1970. (Abadan-Unat, 2006). The migration process has started from Turkey to Europe with these bilateral agreements under the name of 'temporary workers'. The purpose of the process of migration was temporary at first, however in time it has become permanent due to various reasons such as waves of chain migration (family unification, marriage, etc.), educational and economic opportunities, refuge, the formation of the second and third generations, acquiring citizenship, burying their dead in a cemetery assigned for them in the host countries.

At the present time, Turkish immigrants have become a kind of a demographic power that cannot be ignored in the economic, social, cultural and political life of the European countries. According to the statement of the Turkish Ministry of Foreign Affairs, about 5.5 million Turkish people live abroad and 4.6 million have chosen to settle in Western European countries and the rest of them have settled in North America, Asia, the Middle East and Australia. ${ }^{2}$ By means of the ongoing migration process and rising generations in immigrant countries, that number has been growing day by day.

2 See. www.mfa.gov.tr/yurtdisinda-yasayan-turkler_tr.mfa (Accessed date: 30.03.2017). 
Referring the Turks that migrated to European countries as 'temporary workers' in 1960, it is obvious that neither Turkey nor the receiving countries had no policy about migration because of the thought that they would 'go back to their homeland'. Since the late 1970s, the receiving countries' point of view has changed in the way that Turkish immigrants wouldn't be temporary but permanent. So they developed some strategies and policies such as social security laws, repentance laws for illegal or tourist-worker, family reunification laws, foreigner laws etc. The purpose of these new laws/policies was to take the migration wave under control and supporting the immigrant integration in Europe. Turkey as an emigration country, during those days, started to take some serious steps about preventing its own citizens from assimilation and helping them to integrate successfully. It could be counted among these steps that, in Ramadan and Eid Al-adha, the Presidency of Religious Affairs (DIB) sent "seasonal religious officers" to the countries that hosting a big number of Turkish temporary workers in the late 1970s (DIB, General Directorate of External Relations, 2012).

The Presidency of Religious Affairs is an official institution giving public service on religious issues in Turkey. As a constitutional institution, DIB tries to meet society's needs and requirements through internal and external establishments. The external establishment of DIB is organized in countries where Turkish citizens live as the Counsellors of Religious Services connected to the Turkish Embassies. Also, there are semi-official religious foundations in relation to these Offices under the name of 'Turkish Religious Foundations'. In the early 1980s, DIB has started the practice of sending religious officials whose salaries are paid by the Government of the Republic of Turkey, to its external organizations carrying out religious activities within the mosques and masjids. Nowadays, in some Western European countries, such as Germany, Austria, Belgium, Denmark, France, Netherlands, England, Sweden, Switzerland, there are Turkish Religious Foundations and about 1500 mosque unions related to them (see. Çoştu \& Ceyhan Çoştu, 2015).

First attempts of Turkish to be organized in Europe came about in the middle of the 1960s and the very beginning of the 1970s. During those years, the religious life of Turkish immigrants did not seem as a well-structured organization except some personal efforts (Abadan-Unat ,2006). The religious life of the first generations was limited just practising some basic rituals. For that purpose, small flats were rent or purchased. When there was no possibility of returning to homelands, additionally the second and the third 
generation raised there over time so those small places became insufficient. Besides, expectations increased and differentiate so they opened a way for more organized and institutional structure (Küçükcan 1999).

During the migration process, from the early 1960s to the middle of the 1980s, there were not any official religious services for Turkish immigrants living in Europe. For about 20 years, those people had been destined to be on their own. Within that period the activities of religious services had also been carried out mostly by some Turkey based religious groups and communities. Those activities, on one hand, had an important mission with respect to protecting and carrying out immigrant Turks' religious and cultural existence, on the other hand, different religious discourses, ideological and politic activities of the religious groups and communities made it so difficult to live in unity but rather deepened the competition and disintegration.

After nearly 20 years, with the external establishment of DIB in some Western European countries, it can be thought that Turkey has taken immigrant citizens under its wings and government-assisted religious services have been carried out for them. This can be considered as a step to eliminate observed differences in Turkish community and to provide the unity and togetherness of them (Çoştu \& Ceyhan Çoştu, 2015).

In the middle of 1970s, the first religious organizations started to be founded, and their numbers have been increasing day by day. The community expanded the religious services by changing the places they have hired or purchased into mosques or masjids. Those places were not there just for religious practises but also for the educational, social and cultural activities. They have been turned into more institutionalized foundations and organizations in time. At the present day, most of the religious-based foundations and organizations founded by Turkish immigrants somehow are connected with a specific mosque.

\section{III.THE ROLE OF RELIGIOUS GROUPS IN THE DAILY LIVES OF EUROPEAN TURKS}

When Turkish immigrants in various European countries started to lose their hope on returning to their mainland and realised that they were there to stay, the necessity of building their own identity and belonging became obvious. The civic organisations founded by them differentiates in accordance with the ethnic, cultural, ideological and political discourse of each subgroup which 
constitutes the society. Although there is no certain information on the number of civic organisations which belong to Turkish communities living in Europe, it can be observed that these organisations are mainly in the areas/cities heavily populated by immigrant groups.

During the formation period of religious support networks, migration reason, settlement pattern and sense of identity of subgroups, and political, ideological and religious agenda of Turkey had a defining role. (see. Küçükcan, 1999; Perşembe, 2005; Abadan-Unat, 2006; Sirkeci et all., 2016). Social priority differences of immigrants and their religious identity focuses influenced the formation of the mentioned organisations. Furthermore, the fact that there is no one type of culture, political focus, and religious practice in Turkey had also played a significant role in their formation.

Most of the organisations and foundations that have carried out religious services for Turkish Muslim immigrants remind the footprint and local discourses of religious groups, communities, and movements in Turkey. Discourses and political standpoints of these organisations mainly follow the agenda determined in Turkey, and shape their envisagement for the future as well as their envisions of the past according to these ideals (Küçükcan, 2004: Çelik, 2008).

Using a macro-sociological approach, discourses of religious organisations built by Turkish immigrants can be categorised under four main titles:

1. Organisations affiliated with Sufi movements in Turkey and Northern Cypriot: Organisations or associations founded by followers or sympathisers of Mahmut Ustaosmanoglu/Ismail Ağa movement, Muhammed Reşit Erol/Menzil Naqshbandiya Sufi Order, Sheikh M. Nâzım Qibrisî are in this category.

2. Organisations affiliated with religious movements in Turkey: Organisations and associations in this category were built by immigrants who were followers or sympathisers of Suleyman Hilmi Tunahan/Suleymanc1 group, Said-i Nursî/Nur movement and its subgroups. The ones founded by immigrants who had Alevi discourse are also in this category.

3. Organisations affiliated with religious-political movements in Turkey: Organisations founded by immigrants who are members or sympathisers of National Vision/Milli Görüş, Milliyetçiler/Nationalist movement, which have both religious and political discourses, are in this category. 
4. Semi-official religious organisations affiliated with official religious discourse in Turkey: Turkish Religious Foundations (Diyanet) which carry out their activities in conjunction with Religious Services Consultancy under The Embassy of the Turkish Republic in European Countries are in this category. While this variation in religious lives of European Turks can be considered as an affluence, at the same time it can cause serious problems due to the discriminative feature of the differences between religious groups.

Religious places structured under various associations and foundations that belong to Turks in Europe perform many religious and social functions. Service areas of these structures vary on some religious and social factors. The main reasons of these can be explained as below:

These associations or foundations founded by followers or sympathisers of Turkey based religious groups and movements have various religious, political and ideological discourses and aim to protect their specific community structure. This agenda can provoke competition between groups and occasionally tension. These intellectual, social and economic-based tensions could cause disintegration among immigrant communities, as well as could have a role in damaging the group unity and socio-cultural integrity.

Each passing day the number of mosque/masjid/dervish lodge /djemevi centered organisations that belong to European Turks are increasing. This increase brings a rivalry between religious groups. That rivalry caused a race for the domination in religious field. In order to attract immigrants, the religious organizations; first, diversify their service areas, and thus aim to increase the number of their members, and second, make significant efforts to open new religious places, and thus aim to strengthen the institutional structure.

The religiosity understanding of these organisations can sometimes cause problems, which under normal circumstances could be seen as ordinary issues in daily life, but for the citizens living overseas, they can be a significant issue. For example, this situation can be observed in calculations of the daily prayer schedules and the times of pre-dawn meal and fast-breaking meal during Ramadan (see. Perşembe, 2005). Some organisations serving Turkish immigrants follow different time schedules for daily prayers, pre-dawn and fast-breaking meal times. It is known that there are significant differences between the times set by these schedules (see. Çoştu, 2013). These types of 
differences in religious practices among immigrant communities from time to time have an impairing role on protection and maintenance of religious and social harmony, and unity.

Another reason for differentiation in the service areas of religious associations and foundations is related to their different understanding of 'religious identity'. For example, the way that they describe religious identity based on some approaches such as conservatism, nationalism, modernity, ethnic differences and political opinion gives these religious support networks a heterogeneous aspect. Every group shapes their religious attitude and approach in accordance with the criteria they base their religious identity, hence gravitates towards different practice areas, and provides their services accordingly.

Additionally, the service areas of religious groups and movements founded in places heavily populated by Turkish immigrants, and the ones founded in places that Turkish population are scarce also vary. Religious organisations from places heavily populated by Turkish, as a result of the supply and demand factor, and in order to strengthen their institutional structure, provide services in various areas. Besides the differentiation within the context of population density, in the places which have a considerable Turkish population a different level of segregation can be observed. Various religious groups build separate mosques in very close distances and head towards new service areas in order to attract Turkish and Muslim populations living around the mosque.

Another reason for service area differentiation of these organisations is related to the professional competency, education status, age, and language proficiency of the people who provide religious and cultural services. As a matter of fact, services provided by a religious official who has a high education degree, professional competence and language proficiency, and by someone who does not have these qualities cannot be the same.

\section{CONCLUSION}

In European countries, there are many organisations which provide religious and cultural services, aimed at their own immigrant communities as well as other Muslim communities, through religious places (mosque, masjid, derwish lodge, djemev etc.) established by Turkish immigrants living there. These organisations, considering the expectations of their followers, incline towards 
different service areas in these places they have built in accordance with their identity, ideological standpoint, and religious understanding. As a result, religious places of European Turks, connected with other organisations, differ from their roles given in the mainland and turn into places that have social, cultural and educational activities. In these places knowledge is being shared, social networks are being established, and immigrants find a shelter for themselves.

Most of the associations and foundations which predominantly provide religious services to European Turks operate in correlation with religious groups and communities in Turkey. The places these civic structures provide religious services in, and the religious experiences developed within have a heterogeneous nature. This situation, on one hand, have a negative effect on the adaptation period and result in conflicts and rivalry between groups. On the other hand, they act as social solidarity networks and seen as institutionalised products of a struggle to protect and to maintain religious and national identities in a foreign land.

Every religious organisation that belongs to the Turks is structured around some religious place/s (mosque, derwish lodge, djemevi) and have a distinctive community formation. Each one has a specific religious appearance from the content of their religious discourse to their activities. Within the legal rights granted to them by the host countries they conduct religious, cultural and educational activities in order to maintain their integrity and to protect from cultural disintegration.

The activities carried out for immigrants make a significant contribution to the protection of their religious and national identities, by increasing their solidarity and helping them to integrate the countries they reside in. Besides, these places have activities to minimise the possible effects of open or hidden assimilation which second and third generations encounter, therefore seen as natural and matchless shelters by conservative families.

It is observed that the immigrants who stay close or participate in activities of these religious organisations maintain their cultural and religious identities. The ones who have no relations with these places or prefer a secular lifestyle are seem to lose their religious identities and become assimilated linguistically and culturally. 


\section{REFERENCES}

ABADAN-UNAT, Nermin. (2006). Bitmeyen Göç Konuk İşçilikten Ulus-Ötesi Yurttaşliğa, [From Guest Worker to Transnational Citizen]. İstanbul: İstanbul Bilgi Üniversitesi Yayınları. (Turkish).

ADIGÜZEL, Yusuf. (2011). Yeni Vatanda Dini İdeolojik Yapılanma Almanya'daki Türk Kuruluşlar, [Religious and Ideological Situations in the New Homeland; Turkish Organizations in Germany]. İstanbul: Şehir Yayınları. (Turkish).

ALTINTAŞ, İsmail. (2008). Dış-Göç ve Din; Almanya'daki Türklerin Dini Hayatına İlişkin Sosyolojik Bir Çözümleme, [External-Migration and Religion; A Sociological Analysis on the Religious Life of Turks in Germany]. İstanbul: Dem Yayınları. (Turkish).

ARABACI, Fazlı. (1997). "Fransa'da Müslüman Toplumun Örgütlenmesi ve Türk İslam Kimliğini Korumada Cami ve derneklerin Fonksiyonu" [The Organization of Muslim Society in France and the Function of Mosques in the Protection of Turkish Islamic Identity]. Diyanet İlmi Dergi, Cilt: 33, Sayı: 3, ss. 87-106. (Turkish).

ÇELIKK, Celaleddin. (2008). “Almanya'da Türkler: Sürekli Yabancılık, Kültürel Çatışma ve Din”, [Turks in Germany: Continuous Foreignness, Cultural Conflict and Religious]. Milel ve Nihal, cilt: 5, say1: 3, ss. 105-142. (Turkish).

ÇOŞTU, Yakup. (2013). İngiltere'deki Tük-Müslüman Göçmenler; Dini Organizasyonlar, [Turkish Muslim Immigrants in the UK; Religious Organizations]. Çorum: Lider Matbaas1. (in Turkish).

ÇOŞTU, Yakup \& Feyza CEYHAN ÇOŞTU, An Investigation on the Turkish Religious Foundation of the UK (Diyanet)", Turkish Migration, Identity and Integration, Ed. İ. Sirkeci, B. D. Şeker, and A. Çağlar, Transnational Press London, London, 2015. pp. 149-157.

DIB, General Directorate of External Relations, 2012

HATUNOĞLU, Bedri Yavuz. (2002). Hollanda'da Türk Sivil Örgütlenmesi ve Türkevi Örneği, [Turkish Non-Governmental Organizations in the Netherlands and the Case of Turkish House]. (Doktora Tezi), Sakarya: Sosyal Bililer Enstitüsü, Sosyoloji anabilim Dal1, Sakarya Üniversitesi. (Turkish).

HIDIR, Özcan. (2012). Hollanda'daki Türkler; Kurumlar, Başarilar, Sorunlar ve Geleceğe Yönelik Perspektifler, [Turks in Holland; Institutions, Achievements, Problems and Future Perspectives]. Rotterdam: IUR Press. (Turkish).

JORGENSEN, Martin Bak. (2010). "Turks in Denmark: Patterns of Incorporation and Collective Organizing Processes", Insight Turkey, Vol. 12, No. 1, ss. 163-183.

KORKMAZ, Arif. (2011). Göç ve Din; İsveç'teki Kululular Örneği, [Migration and Religion; The Case of Kulu in Sweden]. Konya: Çizgi Kitabevi. (Turkish).

KROISSENBRUNNER, Sabine. (2003). "Islam and Muslim Immigrants in Austria: socioPolitical Networks and Muslim Leadership of Turkish Immigrants", Immigrants \& Minorities, Vol. 22, No: 2\&3, ss. 188-207.

KÜÇÜKCAN, Talip. (1999). Politics of Ethnicity, Identity and Religion Turkish Muslims in Britain, Aldershot: Ashgate.

KÜÇÜKCAN, Talip. (2004). "The Making of Turkish-Muslim Diaspora in Britain: Religious Collective Identity in a Multicultural Public Sphere", Journal of Muslim Minority Affairs, Vol. 24, No. 2, ss. 243-258.

ÖZMEN, Nebile (2012). Çokkültürlü Toplumda Sosyal Entegrasyon ve Din, [Social Integration and Religion in Multicultural Society]. İstanbul: Çamlıca Yayınları. (Turkish).

PERŞEMBE, Erkan. (2005). Almanya'da Türk Kimliği Din ve Entegrasyon, [Turkish Identity in Germany; Religion and Integration], Ankara: Araştırma Yayınları. (Turkish).

ROGSTAD, Jon. (2009). "Towards a Success Story? Turkish Immigrant Organizations in Norway", Turkish Studies, Vol. 10, No. 2, ss. 277-294. 
SİRKECI, İbrahim, T. BİLECEN, Y. ÇOŞTU, S. DEDEOĞLU, M. R. KESİCİ, B. D. ŞEKER, F. TILBE, K. O. UNUTULMAZ, Little Turkey in Great Britain, Transnational Press London, London, 2016.

TRIANDAFYLLIDOU, Anna. (2010). "Muslims in 21 st Century Europe", Muslims in 21 st Century Europe Structural and Cultural Perspectives, Ed. A. Triandafyllidou, New York: Routledge, ss. 1-26.

YANASSMAYAN, Zeynep. (2010). "Role of Turkish Islamic Organizations in Belgium: The Strategies of Diyanet and Milli Görüş", Insight Turkey, Vol. 12, No. 1, ss. 139161

YURDAKUL, Gökçe. (2009). From Guest Workers into Muslims: the Transformation of Turkish Immigrant Associations in Germany, Newcastle upon Tyne: Cambridge Scholars Publishing.

YÜKLEYEN, Ahmet \& Gökçe YURDAKUL. (2011). "Islamic Activism and Immigrant integration: Turkish Organizations in Germany", Immigrants 6 Minorities, Vol. 29, No. 1, ss. 64-85.

http://www.mfa.gov.tr/yurtdisinda-yasayan-turkler_tr.mfa (Accessed date: 30.03.2017) 
